\title{
ВІРШОВАНІ ПРИСВЯТИ ЯК РІЗНОВИД УКРАЇНСЬКОЇ ПАНЕГІРИЧНОЇ ПОЕЗІЇ ДОБИ БАРОКО
}

\author{
СВІТЛАНА ЖУРАВЛЬОВА \\ Бердянський державний педагогічний університет, Бердянськ - Україна \\ zhuravlyova@ukr.net; ORCID: 0000-0001-8089-1867 \\ WIERSZOWANE DEDYKACJE \\ JAKO ODMIANA UKRAIŃSKIEJ POEZJI PANEGIRYCZNEJ \\ OKRESU BAROKU
}

\author{
SWITŁANA ŻURAWLOWA \\ Berdiański Państwowy Uniwersytet Pedagogiczny, Berdiańsk — Ukraina
}

\begin{abstract}
STRESZCZENIE. Barokowe wierszowane dedykacje, których najwcześniejszymi przykładami są wiersze Herasyma Smotryckiego wysławiające księcia Konstantego z Biblii Ostrogskiej, były popularne w XVII i XVIII wieku. Świadczą o tym m.in. utwory Hawryiła Dorofijewicza, Pamwy Beryndy, Łazarza Baranowicza, Jana Armaszenki, Jana Maksymowicza i innych twórców barokowych. Wspomniane wiersze, które umieszczane były na początku ksiąg, nie tylko pełniły funkcję swoistego wprowadzenia, lecz także wysławiały darczyńców oraz magnaterię. Właśnie tym patronom utwory były poświęcone, a sponsorowane przez nich księgi darowane. Istotny jest fakt, że dedykacje panegiryczne często miały podłoże polityczne i odzwierciedlały tendencje ideologiczne sztuki ukraińskiej. Obecnie barokowe wierszowane dedykacje pozostają w literaturoznawstwie ukraińskim poza kontekstem poezji panegirycznej. Jednocześnie wykorzystanie podniosłej topiki oraz sformułowań wysławiających pozwala określić wierszowane dedykacje jako odmianę ukraińskiej poezji panegirycznej okresu baroku.
\end{abstract}

Słowa kluczowe: wierszowane dedykacje, panegiryk, barok, poezja 


\title{
VERSE DEDICATIONS AS A KIND OF UKRAINIAN PANEGYRIC POETRY OF THE BAROQUE ERA
}

\author{
SVITLANA ZHURAVLIOVA \\ Berdiansk state pedagogical university, Berdiansk — Ukraine
}

\begin{abstract}
Baroque verse dedications, the earliest examples of which are Herasym Smotrytskyi's poems in honor of Prince Constantine in the Ostrih Bible, remained popular during the 17th and 18th centuries. This is evidenced, in particular, by Havryil Dorofiievych's, Pamvo Berynda's, Lazar Baranovych's, Ioan Armashenko's, Ioan Maksymovych's texts etc. These poems were placed at the beginning of books to glorify patrons or rulers who donated money to have the books published. In addition, panegyric dedications often had a political background and reflected the ideological vector of the Ukrainian art. Today in the Ukrainian literary criticism Baroque verse dedications largely remain outside the context of panegyric poetry. However, the use of the majestic topic and glorifying formulas makes it possible to classify these dedications as a kind of Ukrainian baroque panegyric poetry.
\end{abstract}

Key words: verse dedication, panegyric, baroque, poetry

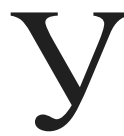

країнська барокова поезія - складна система жанрів, у якій вирізняються тематичні корпуси текстів, напр.: метафізичні, історичні, дескриптивні, агіографічні, панегіричні вірші тощо. Джованна Броджі Беркофф, спираючись на Каталог стародруків Якима Запаска та Ярослава Ісаєвича, слушно робить висновок, що „панегіричні жанри в українських виданнях домінували” [Броджі Беркофф 2012: 21]. Віршові панегірики писали відповідно до настанов поетик і риторик, утім їхній зміст цілковито залежав від суспільно-політичних реалій тогочасної України. Якщо адресатами панегіриків, написаних за часів раннього та зрілого Бароко, були українські церковні ієрархи та гетьмани чи їхнє оточення, то пізньобарокові тексти присвячені переважно московським можновладцям.

В українському літературознавстві традиційно до панегіриків належать ті твори, що були визнані такими ще дослідниками к. XIX ст. і потрапили до радянських підручників та хрестоматій (звісно, ті, що витримали цензуру). Інший поширений спосіб визнання тексту як панегірик - це вказування

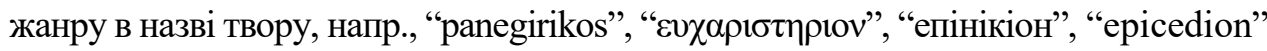
тощо. Однак у літературознавчих розвідках майже не згадують віршованих присвят-панегіриків, поширених в українських виданнях доби Бароко1. Виняток становлять хіба що віршовані присвяти-передмови Гера-

${ }^{1}$ В українській літературі віршовані присвяти меценатам набувають популярності ще за доби Ренесансу. Напр., на початку астрологічної праці Iudicium prenosticon Anni $M C C C C L X X X I I I \ldots$ (Рим 1483) Юрій Дрогобич (Котермак) подає віршовану присвяту папі Сік- 
сима Смотрицького до острозького видання Біблії 1580-1581 pp., що визнані медієвістами взірцями ранньобарокової панегіричної творчості й уже стали "хрестоматійними" текстами.

На сьогодні відсутні спеціальні розвідки, мета яких — аналізування віршованих присвят як панегіричних текстів. Літературознавці приділяють увагу переважно творам Г. Смотрицького як найбільш раннім бароковим панегірикам. Вірші-присвяти на честь меценатів О. Курганова зараховує до молитовної лірики [Курганова 2016: 93], хоч ці тексти мають чітко окреслені панегіричні ознаки. Побіжно згадують українські віршовані присвяти й російські дослідники Л. Сазонова [Сазонова 1981: 181-182] та В. Гребенюк [Русская старопечатная... 1979: 6]. За спостереженням Л. Сазонової, „передмови, післямови та присвяти становлять обов'язкову ознаку українських видань, починаючи зі Львівського Апостола (1574) Івана Федорова, аж до поч. XVIII ст., коли українське книгодрукарство потрапило під нагляд Синоду [...]" [Сазонова 1981: 131] (переклад автор. - С. Ж.). Причина цього, на думку дослідниці, полягає в тому, що „залежність українського книговидання від волі певних осіб, які давали санкції й матеріальні засоби для його розвитку, викликала розквіт теми меценатства й вплинула на надзвичайне поширення ще одного різновиду передмови — присвятного" [Сазонова 1981: 176] (переклад автор. — С. Ж.). Оскільки в українському письменстві доби Бароко чільне місце відводилося поезії, то логічною $є$ й поява віршованих присвят, що слугують “прикнижковим реквізитом” й виконують “структуротвірну роль” [Курганова 2016: 90], тому що вже на початку книги акцентують увагу на iï тематиці. Їх подають переважно на початку книги, одразу після геральдичного вірша, й одночасно вони слугують передмовами. Хоча в українських барокових поетиках серед низки найменувань на позначення панегіричних творів не згадується "віршована присвята" (“афієросис"2), такі тексти, побудовані за всіма законами панегіричного жанру, наявні в багатьох українських виданнях тих часів.

Значна кількість українських віршованих присвят, написаних за доби Бароко, спонукає згадати тут лише деякі тексти: Зри сія знаменія княжате славнаго... та Всякого чина православый читателю... Герасима Смотрицького з острозької Біблії (Острог 1580-1581) [Українська поезія... 1978: 61-65]; До велможного пана, єго милости пана Александра Балабана, старосты въьнничкого і прочая Гавриїла Дорофієвича $з$ книги Иже в святых отца нашего Іоанна Златоустаго архієпископа Константінополя книга о священъствъ... (Львів 1614) [Українська поезія... 1978: 190]; До превелебного въ Христь єго святителскоємилости кир Ієреміи Тисаровского, єпископалвовского и прочая,

сту IV (детальніше див.: М. С. Трофимук, Латиномовна література Украйни XV-XIX cm.: жанри, мотиви, ідеї, Львів 2014).

${ }^{2}$ Грецький термін подає Л. Сазонова в праці Литературная культура России. Раннее Новое время, Москва 2006. 
пана моєго милостивого Памви Беринди з книги На Рождество Господа Бога и спаса нашего Ісус Христа вгоршт для утгххи православным христіаном (Львів 1616) [Українська поезія... 1978: 194]; На єго изарского пресвљтлаго величества мирноє знаменіє Іоана Армашенка з книги Мир з Богом человъку о. Інокентія Гізеля (Київ 1669) [Українська поезія... 1992: 230-232]; Єго изарского пресвътлаго величества россійскому роду Іоана Армашенка 3 книги Синопсис (Київ 1680) [Українська поезія... 1992: 232]; На єго ицарского пресвътлого величества знаменіс Іоана Армашенка 3 книги Минея Общая (Київ 1680) [Українська поезія... 1992: 232-234]; На єго пресвътлаго ияарскаго величества знаменіє... Лазаря Барановича 3 його книги Меч духовный (Київ 1666) [Українська поезія... 1992: 216-217]; Do naiasnieyszego carewicza Theodora Alexiewicza Лазаря Барановича 3 його книги Apollo chrześciański opiewa żywoty świętych, або ж Żywoty świętych ... (Київ 1670) [Baranowicz 1670: 3 нн. - 4 нн.]; Do najaśniejszego hospodara carewicza i wielkiego ksiaśęcia Jana Aleksiewicza wszystkiej, Wielkiej, Małej i Białej Rusi Лазаря Барановича 3 його книги Lutnia Apollinowa, kośdej sprawie gotowa... (Київ 1671) [Baranowicz 2004: 97-98]; На єго ичарскаго пресвтотлаго величества знаменіє... Лазаря Барановича 3 його книги Трубы словес проповъдных ....(Київ 1674) [Українська поезія... 1992: 220-221]; Божію милостю славну иаревичу Алексгъю, велику князю, Петровичу Іоана Максимовича з його поетичної антології Алфавит собранный, риӨмами сложенный... (Чернігів 1705) [Максимович 1705: 6 нн. зв. - 8 нн. зв.].

Саме названі поетичні тексти й слугуватимуть матеріалом цього дослідження. Твори навмисно обрані з різних часових проміжків, оскільки вони ілюструють кардинальні зміни, що відбулися в суспільно-політичному житті України й у середовищі української мистецької еліти.

Українські віршовані передмови часів раннього й пізнього бароко мають класичну композицію панегіриків:

1) уславлення Бога як одвічного Царя всієї землі;

2) розлога хвалебна характеристика адресата та його діянь;

3) молитовне звернення до Господа й святих із проханням допомогти уславлюваній особі. Наявний тут і поширений ще із часів Середньовіччя та актуалізований бароковими митцями топос самоприниження автора: Болше $о$ сем недоумъю, ниже дръзаю писати, / Ини бо о сем множає могуть и лучше сказати [Українська поезія... 1978: 65]; А иж я, нендзный, злота и сребра нъ маю, / О то, чим могу, тым тя, пане мой, витаю [Українська поезія... 1978: 194]; Najaśniejszego i Najwyższego Tronu / Najniższy stuga i bogomodlca ustawiczny... [Baranowicz 2004: 98]; Stuga náyniżzzy czolem biacy / Rythmy zywotow te przynofzacy... [Baranowicz 1670: 4 нн.].

Новим елементом панегіричної композиції стає прохання прийняти книгу як жертовний подарунок (Прійми ж юж ово, як сын иерковный побожный, / упоминок тот, Пане мой [...] [Українська поезія... 1978: 190]; Żywoty 
Świętych Tobie ofiaruię / O Teodorze... [Baranowicz 1670: 3 нн.]) або ж подяка за надані кошти для їі видання (И до друку коштом єго была подана, / И в пожиток межи духовныє роздана [Українська поезія... 1978: 190]).

Уславлення ж адресата (патрона, мецената, самодержця) доволі різниться в цих різночасових текстах. Українські ранньобарокові поети всю похвалу вибудовують довкола книговидавничої діяльності адресата панегірика, усіляко підкреслюючи вагомість його дій для поширення Слова Божого та укріплення православної церкви: Яко вств по чину представил єси Божественноє Писаніс / Истиннаго Бога и правді Сго в похвалу и познаніє, / Да всяк читаяй благольпно благодарить создателя / И да не забываєт достойна мзды свєя дъғлателя... [Українська поезія... 1978: 62]; Владимер бо свій народ крещенієм просвготил, / Константин же благоразумія писанієм освътиил [Українська поезія... 1978: 64]; Як они на такіє речи кошт дають / И розныє книги з друкув на свът выдають... / Выданням книг Церкви Божой помагаючи ... [Українська поезія... 1978: 190].

Віршовані присвяти на честь царів та царевичів авторства Лазаря Барановича, Іоана Армашенка та Іоана Максимовича майже не торкаються теми книговидання, однак у дусі монументалізму звеличують представників монаршого роду як просвітників держави (Пресвгтллый ияарскій дом ваш просвтщаєт [...] [Українська поезія... 1992: 216]), володарів багатьох земель й оборонців віри (Поработи языки и иарствія многа / Яже невтороваша в истиннаго Бога [Максимович 1705: 7 нн. зв.]), поборників ворогів земних і духовних: Благочестісм въры, силою державы, / Врагов души и тъла побъждаєт главы [Українська поезія... 1992: 232]; Камєнь, въри Христовой кргопкий зашититель, / Петр Алєксгєвич всгьх врагов побъдитель. / Скудеянича Магмета царство все сокрушаєт, / Сгда свою каменну силу нань порушаєт. / Нынъ ограду Шведска Лва искореняєт... [Максимович 1705:8 нн.]. Для характеристики московських монархів традиційно застосовано схему, за якою українські поети уславлювали Івана Мазепу. Порушується й тема османської загрози. У цьому контексті Джованна Броджі Беркофф робить висновок щодо причин написання Л. Барановичем двох поетичних книг польською мовою: , [... ] прагнучи поширити книжку при дворі царя, шанувальника польської поезії та кантів, автор, імовірно, мав на меті пропагування свого утопійного плану спільного, римо-католицького й московського, хрестового походу проти османів" [Броджі Беркофф 2012: 31]. Отже, використовуються вже звичні для тодішнього письменства Московської держави „словесні формули, у яких засвідчується територіальна могутність царя” [Елеонская 1981: 74] (переклад автор. - С. Ж.). Іоан Максимович навіть розширює у своєму побажанні межі територіальної експансії Петра I: Пособствующа єму врагов истребити, / Африку, Америку, Азію случити / С Європою, да будет єдина держава, / Царя ПЕТРА Каменя и єдина слава [Максимович 1705: 8 нн.]. В. Гребе- 
нюк визначає ці рядки як “нездійсненні претензії-побажання” та “панегіричну гіперболу”, аргументуючи тим, що цар Петро I ніколи не ставив перед собою такої мети [Русская старопечатная... 1979: 56]. Однак такі побажання цілком уписуються в поширену схему петрівської доби: ,змалювати образ могутнього господаря, володаря багатьох земель, підкреслити його міжнародну славу" [Елеонская 1981: 75] (переклад автор. - С. Ж.), тобто представити царя хай і не всього світу, але переважної його частини. Про це свідчить використання Іоаном Максимовичем поширеної формули, що презентує постать царя як Самодержиа Россіи, многих земль дъдича [Максимович 1705: 7 нн]. Власне, Іоан Максимович запозичує сталі формули, поширені в московських виданнях ще від сер. XVII ст. задля того, щоб „показати великим планом Олексія Михайловича (чи будь-якого іншого представника династії Романових), владного над багатьма землями" [Елеонская 1981: 77] (переклад автор. - С. Ж.). Зауважмо, що Лазар Баранович та Іоан Армашенко ще не використовували такі формули-гіперболи, обмежуючись титулуванням “цар россов".

Українські поети другої пол. XVII - поч. XVIII ст. звертаються до цілком вигаданої, але згодом усталеної серед царських панегіристів схеми відтворення монаршого родоводу. Вони проголошують московських самодержців нащадками рівноапостольного князя Володимира, кровними або духовними, й у такий спосіб апологетизують святість царського роду Романових: Корень Владимер, свят, от єго рода / Свята єст, ияарю, вся ваша порода [Українська поезія... 1992: 217]; Вес бо ваш иарскій корень Богом єст любимый, / От свята ВЛАДИМЕРА до нынг хранимый [Максимович 1705: 7 нн. зв.]. Іоан Максимович ще й подає хвалебну хронологію досягнень попередників Петра I: Князь ӨЕОДОР НИКИТИЧ благородовитій / Славою і честію зъло знаменитій... / Великій государ ияар, велій князь МИХАИЛ / ӨЕОДОРОВИЧ, Шведску Лву уста заградил [Максимович 1705: 7 нн. зв.] тощо.

Митці звертаються й до державницьких образів-символів Орла й орлиних крил, що розглядалися як невіддільний атрибут „усіх жанрів панегіричної літератури Петрівської доби" [Сазонова 2006: 395]: От сего орла орль ся раждают, / Во въниах ияарских, иарми бо бывают [Українська поезія... 1992: 217]; Под кровом Орлих Крыл знамени иарска / Не повредит нас Луна бгссурманска [Українська поезія... 1992: 232]; Orzet Mofkiewski Pioro mi vronit... [Baranowicz 1670: 3 нн.]).

Не позбавлені уваги й образи місяця, сонця та інших небесних тіл, покликані увиразнити велич царського роду (Tbl-сь сонще, жена тебъ луна дана, / А в звъздах, в сынах, плодность обтиана / Царству [...] [Українська поезія... 1992: 221]). Досить поширеним у тогочасній бароковій поезії був прийом етимологічної гри з іменами, зокрема християнськими ${ }^{3}$, завдяки якому під-

\footnotetext{
${ }^{3}$ Детальніше про це: Журавльова С. С., “Петром же быть на той петрг цъгло”: про один із прикладів етимологічної гри з іменем в українській бароковій поезії, [в:] Українська література від давнини до сучасності: парадигми, напрямки, проблеми, Матер. міжвиш. наук. читань (10 жовтня 2017 р.), Запоріжжя 2017, с. 68-70.
} 
креслювали богообраність московських царів. Напр., царевича Олексія поети порівнюють зі святим-тезкою - Олексієм, чоловіком Божим [Українська поезія... 1992: 216-217, 230-232]. Імена Петро, Іоан, Феодор використовують для творення символічних алегорій (Jan taskę znaczy, masz łaskę u Boga, /Z carskiego doти Tobie w niebo droga [Baranowicz 2004: 97]; Феодор, Божій Дар, нынъ иарствуєт [...] [Українська поезія... 1992: 232]; Кто ж постоит от Петра Каменя толика [Максимович 1705: 8 нн.]).

Аналіз віршованих присвят авторства Лазаря Барановича, Іоана Армашенка й Іоана Максимовича демонструє зміни політичного вектора в украінському суспільстві, засвідчує, що ці твори доцільно розглядати в контексті панегіричної літератури часів Петра I, яка „слугувала державі, усебічно підтримувалася, оплачувалася й розповсюджувалася за його кошти" [Русская старопечатная... 1979: 12]. Книги, у яких уміщували віршовані присвяти царям, справді дарувалися московським можновладцям. Напр., С. Маслов віднайшов свідчення, що Іоан Армашенко подарував московському цареві обидві польськомовні книги Лазаря Барановича 1672 р. [Маслов 1925: 12]. Натомість ранньобарокові віршовані присвяти-панегірики висвітлюють специфіку книговидання часів Речі Посполитої й засвідчують, до речі, залежність українських митців від українських меценатів, а не польської шляхти.

Отже, віршовані присвяти в українських барокових виданнях містять величальні топоси, схеми й формули, мають композицію, властиву хвалебним творам. Усе це дає змогу кваліфікувати розглядувані тексти як панегіричну поезію. Отримані результати аналізу спонукають до перегляду усталеної в українському літературознавстві жанрово-тематичної класифікації панегіриків. Зокрема, заслуговують на увагу геральдичні вірші, у яких поети описують насамперед не герб, а уславлюють його власника через детальну інтерпретацію елементів герба, або ж низка епітафій, де домінує панегіричний зміст.

\section{Список використаної літератури}

Броджі Беркофф Дж., Чи існує канон українського літературного бароко?, [в:] „Український гуманітарний огляд", 2012, вип. 16-17, с. 9-54.

Елеонская А. С., Русские старопечатные предисловия и послесловия второй половинь XVI- первой половины XVII в. (патриотические и панегирические темы), [в:] Русская старопечатная литература (XVI-первая четверть XVIII в.). Тематика и стилистика предисловий и послесловий, под ред. А. С. Демина, Москва: Наука, 1981, с. 71-99. 
Курганова О. Ю., Поетична молитва як “текст у тексті” в украӥнських кириличних виданнях доби Бароко, [в:] „Рукописна та книжкова спадщина України”, 2016, вип. 20, c. $90-101$.

Максимович Іоанн, Алфавит собранный, риөмами сложенный.., Чернігів: Друкарня Свято-Троїцького монастиря, 1705.

Маслов С., Етюди з історії стародруків, I-VIII, Київ: ДВУ, 1925 (Відбиток з „Трудів Українського наукового інституту книгознавства", т. I).

Русская старопечатная литература (XVI - первая четверть ХVIII в.). Панегирическая литература петровского времени, изд. подг. В. П. Гребенюк, под ред. О. А. Державиной, Москва: Наука, 1979.

Сазонова Л. И., Украинские старопечатные предисловия кониа XVI - первой половинь XVII в. (борьба за начиональное единство), [в:] Русская старопечатная литература (ХVI-первая четверть ХVIII в.). Тематика и стилистика предисловий и послесловий, под ред. А. С. Демина, Москва: Наука 1981, с.129-152; 156-187.

Сазонова Л. И., Литературная культура России. Раннее Новое время, Москва: Языки славянских культур, 2006.

Українська поезія: кінець XVI - початок XVII cm., упор. В. П. Колосова, В. І. Крекотень, Київ: Наукова думка, 1978.

Українська поезія: середина XVII cm., упор. В. І. Крекотень, М. М. Сулима, Київ: Наукова думка, 1992.

Baranowicz Ł., Apollo chrześciański opiewa żywoty świętych..., Kijów: Z Typographiey Kijowo-Pieczarskiey, 1670.

Baranowicz Ł., Lutnia Apollinowa, kożdey sprawie gotowa ..., Kijów: Z Typographiey KijowoPieczarskiey, 1671, [w:] „Terminus”, 2004, № 2, s. 95-149.

\section{Spysok vykorystanoi literatury (References)}

Brodzhi Berkoff Dzh., Chy isnuie kanon ukrainskoho literaturnoho baroko? [Is There a Canon of Ukrainian Baroque Literature?], [v:] „Ukrainskyi humanitarnyi ohliad”, 2012, vyp. 1617, s. 9-54.

Eleonskaya A. S., Russkie staropechatnye predisloviya i poslesloviya vtoroj poloviny XVI pervoj poloviny XVII v. (patrioticheskie i panegiricheskie temy) [Russian Old-time Printed Prefaces and Afterwords of the Second Half of the XVIth - the First Half of the XVIIth Century. (Patriotic and Panegyric Themes)], [v:] Russkaya staropechatnaya literatura (XVI - pervaya chetvert' XVIII v.). Tematika i stilistika predislovij $i$ posleslovij, pod red. A. S. Dyomina, Moskva: Nauka, 1981, s. 71-99.

Maksymovych Ioann, Alfavit sobrannyi, rifmami slozhennyi... [The Alphabet Gathered and Arranged with the Rhyme...], Chernihiv: Drukarnia Sviato-Troitskoho monastyria, 1705.

Kurhanova O. Yu., Poetychna molytva yak "tekst u teksti" v ukrainskykh kyrylychnykh vydanniakh doby Baroko [Poetic Prayer as a "Text in Text" in Ukrainian Cyrillic Editions 
of the Baroque Age], [v:] „Rukopysna ta knyzhkova spadshchyna Ukrainy”, 2016, vyp. 20, s. $90-101$.

Maslov S., Etiudy z istorii starodrukiv, I-VIII [Studies on the History of the Early Printed Books, I-VIII], Kyiv: DVU, 1925 (Vidbytok z „Trudiv Ukrainskoho naukovoho instytutu knyhoznavstva", t. I).

Russkaya staropechatnaya literatura (XVI - pervaya chetvert`XVIII v.). Panegiricheskaya literatura petrovskogo vremeni [Russian Old-Time Printed Literature (XVIth-First Quarter of the XVIIIth Century). Peter's Time Panegyric Literature], izd. podg. V.P. Grebenyuk, pod red. O. A. Derzhavinoj, Moskva: Nauka, 1979.

Sazonova L. I., Ukrainskie staropechatnye predisloviya konca XVI - pervoj poloviny XVII v. (bor 'ba za nacional 'noe edinstvo) [Ukrainian Old-time Printed Prefaces of the End of the XVIth - the First Half of the XVIIth Century. (Struggle for National Unity)], [v:] Russkaya staropechatnaya literatura (XVI-pervaya chetvert'XVIII v.). Tematika i stilistika predislovij i posleslovij, pod red. A. S. Dyomina, Moskva: Nauka, 1981, s. 129-152;156-187.

Sazonova L. I., Literaturnaya kul tura Rossii. Rannee Novoe vremiya [Russian Literary Culture. Early New Time], Moskva: Yazyki slaviyanskikh kul tur, 2006.

Ukrainska poeziia: kinets XVI-pochatok XVII st. [Ukrainian Poetry: the End of the XVIth-the Beginning of the XVIIth Century], upor. V.P. Kolosova, V.I. Krekoten, Kyiv: Naukova dumka, 1978.

Ukrainska poeziia: seredyna XVII st. [Ukrainian Poetry: the Middle of the XVII th Century], upor. V. I. Krekoten, M. M. Sulyma, Kyiv: Naukova dumka, 1992.

BaranowiczŁ., Apollo chrześciański opiewa żywoty świętych ... [The Christian Apollo is Singing the Lives of the Saints], Kijów: Z Typographiey Kijowo-Pieczarskiey, 1670.

Baranowicz Ł., Lutnia Apollinowa, kożdey sprawie gotowa... [The Apollon's Lute is Ready for Any Cause], Kijów: Z Typographiey Kijowo-Pieczarskiey, 1671, [w:] „Terminus”, 2004, № 2, s. 95-149. 